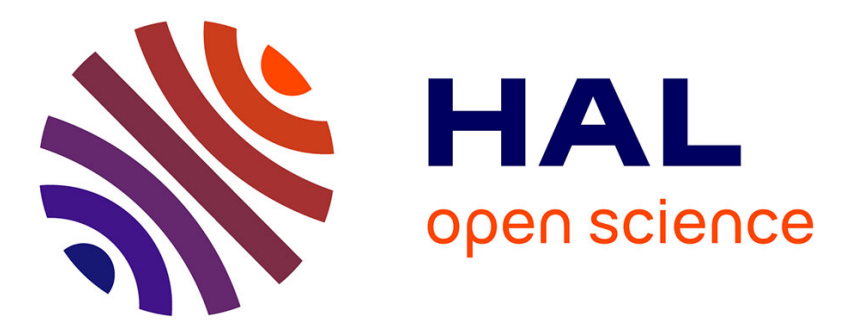

\title{
Food web analysis in two permanently open temperate estuaries: Consequences of saltmarsh loss?
}

\author{
Carl J. Svensson, Glenn A. Hyndes, Paul S. Lavery
}

\section{To cite this version:}

Carl J. Svensson, Glenn A. Hyndes, Paul S. Lavery. Food web analysis in two permanently open temperate estuaries: Consequences of saltmarsh loss?. Marine Environmental Research, 2007, 64 (3), pp.286. 10.1016/j.marenvres.2007.02.002 . hal-00501908

\section{HAL Id: hal-00501908 \\ https://hal.science/hal-00501908}

Submitted on 13 Jul 2010

HAL is a multi-disciplinary open access archive for the deposit and dissemination of scientific research documents, whether they are published or not. The documents may come from teaching and research institutions in France or abroad, or from public or private research centers.
L'archive ouverte pluridisciplinaire HAL, est destinée au dépôt et à la diffusion de documents scientifiques de niveau recherche, publiés ou non, émanant des établissements d'enseignement et de recherche français ou étrangers, des laboratoires publics ou privés. 


\section{Accepted Manuscript}

Food web analysis in two permanently open temperate estuaries: Consequences of saltmarsh loss?

Carl J. Svensson, Glenn A. Hyndes, Paul S. Lavery

PII: S0141-1136(07)00029-3

DOI: 10.1016/j.marenvres.2007.02.002

Reference: MERE 3102

To appear in: Marine Environmental Research

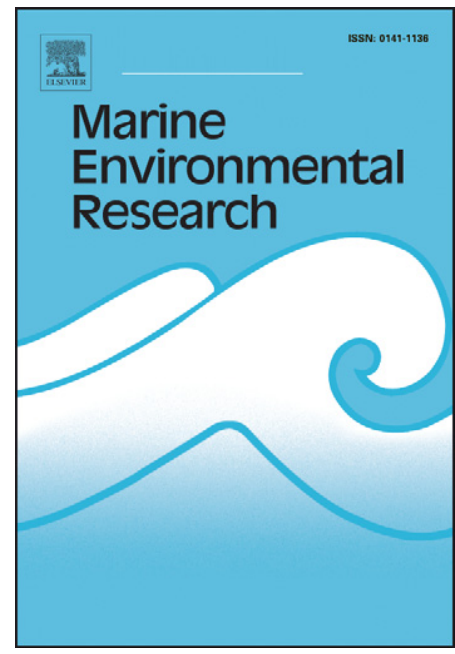

Received Date: $\quad 15$ December 2006

Revised Date: $\quad 5$ February 2007

Accepted Date: $\quad 6$ February 2007

Please cite this article as: Svensson, C.J., Hyndes, G.A., Lavery, P.S., Food web analysis in two permanently open temperate estuaries: Consequences of saltmarsh loss?, Marine Environmental Research (2007), doi: 10.1016/ j.marenvres.2007.02.002

This is a PDF file of an unedited manuscript that has been accepted for publication. As a service to our customers we are providing this early version of the manuscript. The manuscript will undergo copyediting, typesetting, and review of the resulting proof before it is published in its final form. Please note that during the production process errors may be discovered which could affect the content, and all legal disclaimers that apply to the journal pertain. 
Running head: Tracing primary production in food webs

Food web analysis in two permanently open temperate estuaries: consequences of saltmarsh loss?

\section{Carl J. Svensson, ${ }^{1}$ Glenn A. Hyndes ${ }^{2}$, Paul S. Lavery ${ }^{2}$}

${ }^{1}$ Department of Marine Ecology, Göteborg Universit y, Box 461, SE 40530 Göteborg, Sweden

${ }^{2}$ Centre for Ecosystem Management, School of Natural Sciences, Edith Cowan University, 100 Joondalup Dr. 6027 Joondalup, West Australia

Correspondence; C. J. Svensson, email: johan.svensson@marbot.gu.se, tel: +46317732627 


\section{Abstract}

Saltmarsh vegetation, seston and microphytobenthos are all conspicuous components of most temperate estuaries and they potentially contribute to the estuarine food chain. Yet their relative contributions are unclear, as is the significance of saltmarsh losses through natural and human-induced impacts. This study aimed to quantitatively determine the contribution of various types of primary producers to detritus in the Walpole-Nornalup Estuary and Leschenault Inlet, two permanently-open estuaries in SW Australia, and, estimate the flow of different types of detritus to higher trophic levels, using carbon $\left({ }^{13} \mathrm{C}\right)$ and nitrogen $\left({ }^{15} \mathrm{~N}\right)$ stable isotopes as tracers. Results of the mixing model indicated that seston, microphytobenthos and to some extent seagrass and fringing saltmarsh were the main contributors to the detrital pool in both estuaries. However, the relative contribution of different primary producers varied both within and between estuaries. The contribution of saltmarsh was higher at sites close to rivers and dense fringing vegetation, while seston, microphytobenthos and seagrass dominated the detrital material at other sites. Benthic harpacticoid copepods were shown to feed on detritus though they appeared to actively select for different components of the detritus depending on site and estuary. Isotopic signatures of other consumers indicated that fish and invertebrates derived nutrients from MPB and detritus, either directly as food or indirectly through feeding on invertebrates. The overall contribution of saltmarsh to detritus was lower in Leschenault Inlet than in Walpole-Nornalup Estuary, possibly as a result of increased clearing of fringing vegetation around Leschenault Inlet. This pattern was however not reflected in harpacticoid food. Therefore, although losses of fringing saltmarsh around estuaries have the potential to significantly affect estuarine food webs, the significance of such losses will be site- and estuary- dependent. 
Keywords: estuarine food web, stable isotopes, detritus, fringing vegetation, clearing 


\section{Introduction}

Estuaries worldwide provide a focal point around which many coastal communities develop and grow. Fisheries, agriculture and other industries prosper in and around estuarine ecosystems and form a large economic resource for these communities, placing estuarine environments under increasing pressure from human disturbances. Since a healthy estuary is inherent to the ecological, cultural and economic coastal society, it is important to find tools that allow us to evaluate the effect these developments might have on estuarine processes.

Estuarine saltmarsh vegetation is under threat at a global scale through the potential impact of global sea-level rise (Knogge et al. 2004), and at a local scale due to losses from natural and human-induced disturbances (e.g. Pen et al. 2000; Harty and Cheng 2003). Development and hydrological changes affect the distribution and biomass of fringing vegetation, but the significance of those changes is unclear. Where estuarine foodwebs are reliant on significant inputs from fringing saltmarsh and macrophytes, there is the potential for flow-on effects to higher trophic levels, such as large invertebrates and fish (e.g. Loneragan and Bunn 1997; Kwak \& Zedler 1997). However, the literature suggests a varied role for this material in the diet of estuarine organisms. In some studies, marsh detritus and seagrass have been shown important as food sources to estuarine invertebrates (Zieman et al. 1984; Thresher 1992; Riera

et al. 1996; Kwak and Zedler 1997; Loneragan and Bunn 1997; Castellanos and Rozas 2001), while other studies have shown that filamentous algae, microphytobenthos (MPB) and phytoplankton are the preferred food (e.g. Haines 1976; Kwak and Zedler 1997; Le Point et al. 2000, Moens et al. 2002; Riera and Hubas 2003).

The trophic transfer of energy from primary producers can involve several possible mechanisms, but it is clear that meiofaunal assemblages, such as copepods and nematodes, 
play an important role in the transfer of nutrients from detritus to higher trophic levels (Carman and Thistle 1985; Kennish 1990; Cabana and Rasmussen 1996; Riera et al. 1996; Coull 1999; Carman and Fry 2002). In turn, meiofauna, which are typic ally abundant in estuarine sediments, present a food source to larger invertebrates and fish (Coull et al. 1995; Coull 1999). Invertebrates and fish can also consume detritus directly (Odum 1980; Kennish 1990; Constable 1999), although surface microbes and microphytobenthos may be assimilated rather than detrital material (Cammen 1980; Zieman et al. 1984).

In temperate Australian estuaries, there is limited information on the contribution of primary producers to food web structure, particularly quantitative estimates of the relative contributions of primary producers to detritus and first order consumers (e.g. Cook et al. 2004). Several studies assume contributions of particular primary producers to fish production without first adequately linking primary p roduction with first-order consumers (e.g. Bulman et al. 2001; Mazumder et al. 2006). Producing quantitative estimates would add insight into the role of saltmarsh in the production of detritus and the support of higher trophic levels in temperate Australian estuaries, facilitating an evaluation of the potential consequences of alterations in the primary producer composition for the tropho-dynamics of these systems. Saltmarsh in these regions are affected by direct clearing of fringing vegetation for development and agriculture (e.g. Hodgkin and Clark 1988; Hodgkin 1998), as well as management efforts to alter hydrological regimes to promote greater ocean connection (Hodgkin 1998).

The first aim of this study was to identify, through the natural abundance of carbon and 


\section{ACCEPTED MANUSCRIPT}

nitrogen isotopes, the main primary producers that contribute to detrital material and first order consumers and to examine the flow of material to higher trophic levels in two permanently open estuaries in south-west Australia. The second aim was to evaluate whether any contribution of those primary producers vary within and between these estuaries. 


\section{Methods and Materials}

\section{Study area}

Two permanently open estuaries in south-west Australia were selected for the study. The Walpole-Nornalup estuary consists of two basins and the lower reaches of the Deep, Frankland and Walpole rivers (Figure 1). Depths range from 0 to $5 \mathrm{~m}$. Tidal influence and the level of exposure at the south coast allow marine water to intrude several kilometres up the Frankland and Deep rivers. The region experiences high annual precipitation rates $(\approx 1400$ $\mathrm{mm}$ ), and low evaporation rates ( $\approx 600 \mathrm{~mm}$ ) (Hodgkin and Clark 1988). Heavy rainfall may stratify the estuary, but the deep waters rarely experience salinities lower than $30 \%$. Water temperature changes seasonally $\left(8-24 C^{\circ}\right)$, but is hardly ever uniform throughout the water column (Hodgkin and Clark 1988). Juncus kraussi dominates the fringing macrophytes and among the seagrass, Halophila sp. and Ruppia megacarpa are common. The WalpoleNornalup estuary is principally surrounded by conservation estate and has largely intact fringing vegetation with the exception of some recreational areas.

Leschenault Inlet consists of one large basin with the Collie and Preston rivers discharging into the estuary near the ocean opening (Figure 1). It covers $27 \mathrm{~km}^{2}$ and rarely exceeds $2 \mathrm{~m}$ in depth. Annual precipitation and evaporation averages at $875 \mathrm{~mm}$ and $1200 \mathrm{~mm}$ respectively (Hillman et al. 2000). Tidal fluctuations and wind keep the water well mixed and Leschenault remains essentially marine throughout the year except for the northern region, which becomes

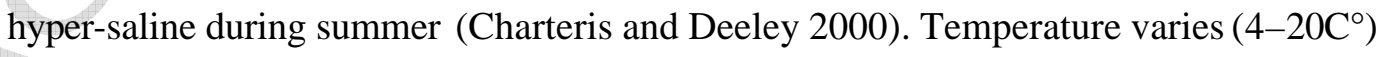
depending on local weather and the intrusion of colder water from the ocean. Juncus kraussi and to some extent the parkland grass Paspalum vaginatum dominate the fringes, while the submerged macrophyte species composition is dominated by seagrasses and brown algae, although semi attached green algae can contribute to a significant portion of total macrophyte 
biomass seasonally (Hillman et al. 2000). In Leschenault Inlet, 50\% of an estimated 700ha of fringing vegetation had been lost through industrial and recreational developments between the 1940s and 1990s (Pen et al. 2000).

\section{Data collection}

Three sites were sampled within each estuary. Their location encompassed much of the known spatial variability of each estuary with respect to the potential influence of saltmarsh, riverine and marine vegetation. During April 2001, detritus and a range of primary producers and consumers were sampled at each site in both estuaries. Where possible, three or four samples of each type of material or taxa were collected from each site. For some small organisms (phytoplankton, seston and meiofauna), high numbers were required for the stable isotope analysis and, therefore, one or two pooled samples were collected from each site.

\section{Detritus and primary producers}

The upper detrital layer $(\approx 10 \mathrm{~mm})$ surfacing the bottom sediment was collected at each site with a $125 \mu \mathrm{m}$ sweep net until the mesh clogged up. Samples were then filtered through a series of 500, 63 and $20 \mu \mathrm{m}$ mesh sieves and the $20-63 \mu \mathrm{m}$ size-class of detrital particles was filtered onto pre-combusted $\left(600^{\circ} \mathrm{C}\right.$ for $\left.5 \mathrm{~h}\right)$ Glass Fiber $/ \mathrm{C}(\mathrm{GF} / \mathrm{C})$ filters and frozen for further processing.

Plankton were isolated by pumping approximately 5001 of estuarine water from a depth of $0.5 \mathrm{~m}$ through a $500 \mu \mathrm{m}$ sieve placed above two cone nets, one of $100 \mu \mathrm{m}$ mesh placed inside another of $20 \mu \mathrm{m}$ mesh. The $100-500 \mu \mathrm{m}$ sample was considered to contain zooplankton while the 20-100 $\mu \mathrm{m}$ sample was considered to contain seston (phytoplankton and some detritus). Seston samples were examined under a microscope to determine the proportions of 
phytoplankton and detritus in the sample. Samples were filtered onto precombusted GF/C filters, packed in aluminium foil and stored on ice for further processing. Due to the low abundance of zooplankton, they were regarded as one group and not separated into species or functional groups. Zooplankton were separated from large debris manually and then put in GF/C filtered seawater for at least $24 \mathrm{hrs}$ to depurate.

Microphytobenthos (MPB) were sampled from the upper layer $(\sim 2 \mathrm{~cm})$ of sediment from patches with little visible detritus. The sediment was collected with a small trowel, placed in a volumetric flask with distilled water and shaken to separate the algal cells from the sediment grains (median size $\sim 1 \mathrm{~mm}$ ). Microscop ic analysis confirmed that the suspension contained mainly MPB and detritus. This solution was filtered through a series of 500, 120 and $63 \mu \mathrm{m}$ five times to clean the sample from most fauna and large detritus. The volumetric proportion of detritus in the samples was determined through microscopical analysis of 10 sub-samples of each sample, prior to packing the samples in aluminium foil, and freezing.

Leaves, stems and roots from terrestrial plants and seagrasses were collected from abundant species at each site. For macroalgae, whole thalli were collected. Samples were rinsed in distilled water and then frozen.

\section{Consumers}

Meiofauna (63 -500 $\mu \mathrm{m})$ were collectedby divers using a $125 \mu \mathrm{m}$ sweep net to scoop over $250 \mathrm{~m}$ of sediment surface. After collection, the material was filtered through 1000 and 500 $\mu \mathrm{m}$ mesh sieves to remove macrofauna and large debris. The sediment was then allowed to 
settle and the supernatant water was poured through a $63 \mu \mathrm{m}$ mesh sieve to retain meiofauna and detrital material of 63-500 $\mu \mathrm{m}$. Amodification of Couch's $(1988,1989)$ method was used to concentrate and isolate debris-free copepods from the filtrate. The method comprised letting the copepods swim towards an isolated light-source concentrated to a small hole in an otherwise opaque box. By connecting a syringe directly to the hole we could easily extract vast amounts of debris free copepods. The isolated copepods were left in filtered seawater for $24 \mathrm{hrs}$ to depurate, after which they were poured through a $63 \mu \mathrm{m}$ mesh sieve into a clean container and rinsed with Milli Q water. This procedure was repeated four times to clean the sample from crystallising ions and possible gut-contents. The sample was then sorted into harpacticoid, calanoid and cyclopoid copepods. Other meiofauna were extracted using the method explained for extracting MPB. Nematodes and larvae were then separated manually from detritus under a high precision dissecting microscope, and kept in separate tanks of filtered seawater for $24 \mathrm{hrs}$ to depurate their guts. All meiofauna samples were then filtered onto precombusted GF/C filters, packed in aluminium foil and frozen.

Benthic macrofauna $(>500 \mu \mathrm{m})$ in the sediments were sampled to a depth of $20 \mathrm{~cm}$ using a 10 -cm-diameter core. The sediment was then washed through a series of g raded sieves. Invertebrates from the sieved sediment were separated from detritus and sorted into size classes and broad taxonomic groups, and then kept in filtered seawater for 24 hrs to depurate their guts. Muscle tissue from gastropods, bivalves and large crustaceans were removed from their cases or shells. For other organisms, the whole animal was retained, packed in plastic containers and frozen. 
Fish were caught at each site using a seine net. The seine net was $21 \mathrm{~m}$ long and $1.5 \mathrm{~m}$ high with $0.6-0.9 \mathrm{~cm}^{2}$ woven mesh, while the gill net was $40 \mathrm{~m}$ long and $4 \mathrm{~m}$ high with $4-8 \mathrm{~cm}^{2}$ mesh. On capture, fish were immediately anaesthetised in a bath of $1 \%$ Benzocaine, resulting in euthanasia. Fish were then placed in ice slurries for muscle dissection in the laboratory. For large fish, a small sample of muscle from the dorsal flank was collected and then the animal was released with minimum handling. Samples of muscle tissue were collected from all fish and stored in ependorf tubes on ice for further processing.

\section{Stable isotope analysis}

Since muscle tissue comprises a large part of the organism and has been shown to represent intermediate $\delta^{13} \mathrm{C}$ and $\delta^{15} \mathrm{~N}$ levels (Wada and Mizutani 1991), muscle tissue was used for the isotope analyses of most invertebrates and fish. All samples of copepods, amphipods and other small crustaceans were washed in $1 \mathrm{M} \mathrm{HCl}$ to remove inorganic carbon (Bunn and Boon 1993). Because acid-washing can affect the nitrogen stable isotopic content (Rolff 2000, McCutchan et al. 2003), a separate sub sample was removed prior to acid-washing and prepared for $\delta^{15} \mathrm{~N}$ analysis. Since between $600-1000$ copepods were required for stable isotope analysis, all cyclopoid and some calanoid copepod samples were excluded as they had insufficient biomass. For nematodes, polychaetes and some crustaceans, samples were pooled to ensure sufficient biomass for analysis. All samples and filters were dried separately at $70^{\circ} \mathrm{C}$ until completely dry, ground in a mortar with a pestle to a fine powder, re-dried and then placed in ependorf tubes and stored at $-20^{\circ} \mathrm{C}$.

Stable isotopic ratios for ${ }^{15} \mathrm{~N} /{ }^{14} \mathrm{~N}$ and ${ }^{13} \mathrm{C} /{ }^{12} \mathrm{C}$ were determined for all samples using a Europa 
ANCA-GSL (gas/solid/liquid) 20-20 Mass Spectrometer. The precision (internal and external) of the measurement was $0.3 \%$ for nitrogen and $0.2 \%$ for carbon. Reference samples of 2 mg of flour and 1.5 -3 mg of glutamic acid were used for the ${ }^{15} \mathrm{~N} /{ }^{14} \mathrm{~N}$ and ${ }^{13} \mathrm{C} /{ }^{12} \mathrm{C}$ analysis, respectively (Barrie and Prosser 1996). Two samples of each species or group were analysed to correct for measurement error. All results were reported as $\delta^{13} \mathrm{C}$ or $\delta^{15} \mathrm{~N}$ relative to Pee Dee belemnite and atmospheric nitrogen gas, respectively, against which the reference samples were standardised.

\section{Data analysis}

The Isosource mixing model (Phillips \& Gregg 2003) was used to estimate the potential range contribution of primary producers, firstly to detritus, and secondly, to harpacticoid copepods, which are known to feed on detritus (Higgins and Thiel 1988; Couch 1989) and form an important part of the food chain (Coull 1999). Analyses focused on using average data for the major sources of production, detritus and copepods from each site in each estuary to examine the system-wide and spatial variability of contributions of primary producers to detritus. Even though replicate samples of some producers (i.e. MPBs and phytoplankton) and harpacticoid copepods were not available, those single samples were collected over large areas (approximately $2500 \mathrm{~m}^{2}$ ) containing thousands of individuals and therefore provide a representative value for each site, capturing variability on the same spatial scale as the other consumers and primary producers which were analysed. When only one or two stable isotopes are used, fewer sources add precision to the analysis (Phillips and Gregg 2003). However, when too many sources are combined the mean becomes indeterminate due to increased variation. There is thus a trade-off between using fewer sources or more accurate means. In 
this study, we have chosen to combine plants or algae that comprise the same functional group if differences in either stable isotopic signature (i.e. $\delta^{15} \mathrm{~N}$ or $\delta^{13} \mathrm{C}$ ) were less than $20 \%$.

The frequency and range of the possible contribution (0-100\%) of each possible source at increments of $1 \%$ were determined (see Phillips and Gregg 2003 for details) using both $\delta^{13} \mathrm{C}$ and $\delta^{15} \mathrm{~N}$ values for detritus and only $\delta^{13} \mathrm{C}$ values for copepods since the enrichment of $\delta^{15} \mathrm{~N}$ between trophic levels has been shown to vary considerably for marine invertebrates (McCutchan et al. 2003; Vanderklift and Ponsard 2003). Including $\delta^{15} \mathrm{~N}$ values would therefore have added to the uncertainty of the model outputs. Further, since $\delta^{13} \mathrm{C}$ exhibits little or no enrichment between trophic groups (McCutchan et al. 2003; Staddon 2004), $\delta^{13}$ C values of consumers were not adjusted for fractionation in the mixing model analyses. Mixing model analyses were combined with graphical analyses to affirm and validate mixing model outputs. The $\delta^{13} \mathrm{C}$ and $\delta^{15} \mathrm{~N}$ values of higher trophic levels were only analysed graphically. 


\section{Results}

\section{Isotopic characteristics for primary producers}

In Walpole-Nornalup estuary, $\delta^{13} \mathrm{C}$ and $\delta^{15} \mathrm{~N}$ values of primary producers varied greatly, from -34.4 to $-9.9 \%$ or for $\delta^{13} \mathrm{C}$ and from 3.1 to $8.6 \%$ o for $\delta^{15} \mathrm{~N}$ (Table 1 ). The $\delta^{13} \mathrm{C}$ values of the primary producers fell into three groups. The first group consisted of saltmarsh vegetation and, with the exception of the introduced grass Paspalum vaginatum $\left(\delta^{13} \mathrm{C}=-13 \%\right.$ ), had low $\delta^{13} \mathrm{C}$ values between -29 and $-24 \%$. The second group comprised seston, MPB and macroalgae, which had $\delta^{13} \mathrm{C}$ values ranging from -22.0 to $-15.7 \%$ (except for the filamentous red algae Gracilaria gracilis, which had $\delta^{13} \mathrm{C}<-30 \%$ ). However, seston and MPB samples contained detritus (10, 10 and 20\% in seston samples, and, 10, 20 and 20\% in MPB samples for site 1, 2 and 3 respectively). The third group comprised the seagrasses Halophila ovalis and Zostera tasmanica, with high $\delta^{13} \mathrm{C}$ values between -15.8 and $-9.9 \%$. Mean $\delta^{15} \mathrm{~N}$ values of primary producers were highly variable and the greatest variation was found for saltmarsh vegetation $(3.1$ to $8.6 \%$ ).

Mean $\delta^{13} \mathrm{C}$ and $\delta^{15} \mathrm{~N}$ values for primary producers in the Leschenault Inlet were comparable to those in Walpole-Nornalup. Similarly, primary producers could be separated into three groups of low, intermediate and high $\delta^{13} \mathrm{C}$ values (Table 1). The first group had $\delta^{13} \mathrm{C}$ values close to $26 \%$ and constituted saltmarsh vegetation, with the exception of Paspalum vaginatum $\left(\delta^{13} \mathrm{C}=\right.$ $-13 \%$ ). The second group had $\delta^{13} \mathrm{C}$ values between -15.4 and $-22.2 \%$ and included seston, MPB and filamentous algae. Seston and MPB samples contained detritus (10, 20 and 15\% in seston samples, and, 20, 15 and 25\% in MPB samples for site 1, 2 and 3 respectively). The third group comprised seagrasses, which had high $\delta^{13} \mathrm{C}$ values ranging from $-8.1 \%$ to $-8.7 \%$ o 
(Table 1). As for Walpole-Nornalup, mean $\delta^{15} \mathrm{~N}$ values of primary producers were highly variable and the greatest variation was found for saltmarsh vegetation (2.5 to $11.3 \%$ ).

\section{The contribution of primary producers to detritus and harpacticoid copepods}

There was little spatial variability in the $\delta^{13} \mathrm{C}$ and $\delta^{15} \mathrm{~N}$ values of detritus among sites in

Walpole-Nornalup (Table 1). Mean $\delta^{13} \mathrm{C}$ values of detritus ranged from -19.6 to $-21.7 \%$ while mean $\delta^{15} \mathrm{~N}$ values ranged from 4.6 to $6.0 \%$. Results from the mixing model demonstrated that seston, MPB and terrestrial vegetation were potential contributors to detritus at all sites in the Walpole-Nornalup estuary (Figure 2a-c). These results seem viable based only on the stable isotope signatures of these groups (Figure 4). There was generally a higher contribution of saltmarsh to detritus at sites closer to rivers and dense terrestrial vegetation, such as the Walpole basin where the median potential contribution was 0.4 (Figure 2c). Seagrasses and filamentous algae yielded large ranges of contributions to detritus outside the Walpole basin (Figure 2a-c). Seagrasses were the main contributors to detritus at W2, while filamentous algae were the dominant contributors to detritus at W1, closest to the ocean opening.

$\delta^{13} \mathrm{C}$ and $\delta^{15} \mathrm{~N}$ values of harpacticoid copepods varied greatly across sites in the WalpoleNornalup Estuary, ranging from -20.2 to $-11.3 \%$ and 4.4 to $8.8 \%$ o respectively (Table 1 ). Consequently, the mixing model indicated that the sources of ${ }^{15} \mathrm{~N}$ and ${ }^{13} \mathrm{C}$ to harpacticoid food were slightly different to those of detritus (Figure 2a-c and 3a-c). The largest differences were found at W1 where seagrasses contributed more and red algae less to harpacticoid food than to detritus (Figure 3). Across sites, the overall contribution of saltmarsh to harpacticoids was slightly lower than it was to detritus. 
Compared to Walpole-Nornalup Estuary, the $\delta^{13} \mathrm{C}$ values of detritus were on average $3 \%$ o higher in Leschenault Inlet, where they ranged from -16.9 to $-14.5 \%$. However, $\delta^{15} \mathrm{~N}$ values were similar, ranging from 3.7 to $6.9 \%$ in Leschenault Inlet. Results from the mix ing model indicated that detritus in the Leschenault Inlet comprised a more even mix of potential contributors than Nornalup -Walpole (Figure 2d -f). Seston, MPB, seagrass, saltmarsh and algae were all contributing to detritus, which appear viable based on the stable isotope signatures of these groups (Figure 5). However, as for Walpole-Nornalup, the detritus composition varied across sites. For example, the contribution of saltmarsh vegetation to detritus was greater at locations closer to rivers (Figure 2e) while seagrasses showed high contributions at all sites (Figure $2 \mathrm{~d}-\mathrm{f}$ ).

Compared with Walpole-Nornalup Estuary, $\delta^{13} \mathrm{C}$ and $\delta^{15} \mathrm{~N}$ values of harpacticoid copepods in Leschenault Inlet were less variable among sites, ranging from -17.6 to $-15.0 \%$ and 4.5 to $7.8 \%$ respectively (Table 1 ). This was reflected in the mixing model outputs, which indicated that the contribution of the various primary producers to harpacticoids and detritus were similar (Figure $2 \mathrm{~d}-\mathrm{f}$ and $3 \mathrm{~d}-\mathrm{f}$ ). Aversions from this pattern were a high contribution of the introduced grass Paspalum vaginatum to detritus at L2 and a high contribution of saltmarsh to harpacticoids at L3.

\section{Invertebrates and fish}

The increase in $\delta^{13} \mathrm{C}$ and $\delta^{15} \mathrm{~N}$ values from detritus to fish was equivalent to three to four trophic levels (Tables 1 and 2, Figure 4). However, stable isotopic signatures for meiofauna 
and macrofauna overlapped, indicating several possible trophic pathways from detritus to fish (Figure 4). Zooplankton in Walpole-Nornalup Estuary were slightly enriched in ${ }^{13} \mathrm{C}$ and ${ }^{15} \mathrm{~N}$ compared to seston, MPB and detritus (Table 1, Figure 4). Meiofauna generally had $\delta^{13} \mathrm{C}$ and $\delta^{15} \mathrm{~N}$ values similar to or slightly higher than did MPB and seagrasses. Nereids and platyhelminthes varied in their $\delta^{13} \mathrm{C}$ and $\delta^{15} \mathrm{~N}$ values, which were similar to seagrasses. Most crustaceans were slightly enriched in ${ }^{13} \mathrm{C}$ and ${ }^{15} \mathrm{~N}$ compared to meiofauna and MPB, gastropods had $\delta^{13} \mathrm{C}$ and $\delta^{15} \mathrm{~N}$ values similar to MPB and detritus, and bivalves had $\delta^{13} \mathrm{C}$ and $\delta^{15} \mathrm{~N}$ values similar to seston (Table 2, Figure 4). Smaller and medium-sized fish had elevated $\delta^{13} \mathrm{C}$ and $\delta^{15} \mathrm{~N}$ values compared to detritus, meiofauna and smaller invertebrates (Figure 4). Larger fish, such as sharks and rays, were enriched in both ${ }^{13} \mathrm{C}$ and ${ }^{15} \mathrm{~N}$ compared to most species (Figure 4, Table 2).

In Leschenault Inlet, compared to Walpole-Nornalup Estuary, the ${ }^{13} \mathrm{C}$ and ${ }^{15} \mathrm{~N}$ content of biota showed a clearer trophic structure from detritus to invertebrates and from invertebrates to fish (Figure 5). Notable is that many fish species followed the pattern of detritus, and had $\delta^{13} \mathrm{C}$ values approximately 3\%o higher than their counterparts in Walpole-Nornalup (Table 2). Overall, assuming an enrichment of $0-1 \%$ o for ${ }^{13} \mathrm{C}$ and $3-4 \%$ for ${ }^{15} \mathrm{~N}$ per trophic level, there was an increase in $\delta^{13} \mathrm{C}$ and $\delta^{15} \mathrm{~N}$ values from detritus to fish that was equivalent to between two and three trophic levels (Tables 1 and 2, Figure 5). Zooplankton were slightly enriched in ${ }^{13} \mathrm{C}$ and ${ }^{15} \mathrm{~N}$ compared to seston (Table 1) and meiofauna had ${ }^{15} \mathrm{~N}$ and ${ }^{13} \mathrm{C}$ contents similar to detritus and MPB. Nereids and platyhelminthes were slightly enriched in ${ }^{13} \mathrm{C}$ and ${ }^{15} \mathrm{~N}$ compared to detritus and meiofauna (Table 2, Figure 5), while small crustaceans had $\delta^{13} \mathrm{C}$ and $\delta^{15} \mathrm{~N}$ values similar to detritus, meiofauna and MPB. Larger crustaceans had ${ }^{15} \mathrm{~N}$ and ${ }^{13} \mathrm{C}$ 
contents reflecting a varied diet. Gastropods had stable isotopic signatures close to those for detritus and meiofauna and bivalves had $\delta^{13} \mathrm{C}$ and $\delta^{15} \mathrm{~N}$ values similar to green algae and seston (Figure 5). Smaller fish were slightly enriched in ${ }^{13} \mathrm{C}$ and ${ }^{15} \mathrm{~N}$ compared to detritus, meiofauna and MPB, while medium-sized fish were enriched in ${ }^{13} \mathrm{C}$ and ${ }^{15} \mathrm{~N}$ compared to invertebrates (Table 2, Figure 5). Rays had $\delta^{13} \mathrm{C}$ and $\delta^{15} \mathrm{~N}$ values that were slightly higher than other fish species. 


\section{Discussion}

The detritus composition in the two estuaries studied constituted a mix of all primary producers though the composition varied both within and between estuaries. Furthermore, the mixing model outputs and graphic analyses provided evidence that living seston and MPB together with the bulk of estuarine detritus were the main contributors to invertebrate and fish production in the Walpole-Nornalup and Leschenault estuaries. Since saltmarsh was a conspicuous component in the detritus, clearing could potentially affect food web structure and production. However, seston, MPB and seagrass seemed to be the most important contributors to the food webs in these estuaries, either through the grazing or detrital pathway.

When interpreting the results it must be considered that this study was conducted at a single point in time. Seasonal fluctuations in the physical environment, such as temperature, salinity, light and oxygen concentration, can impinge on the ${ }^{13} \mathrm{C} /{ }^{12} \mathrm{C}$ ratio of organisms (Troughton and Card 1975, Smith and McMillan 1976, Guy et al. 1980, Rolff 2000) and also on invertebrate food consumption (Montagna and Yoon 1991; Carman and Fry 2002). It is therefore possible that at other times of the year, isotopic analysis could reveal different contributions of primary producers to detritus and harpacticoids. Furthermore, the microbial processes during organic breakdown are poorly investigated and there was a potential for fractionation to have occurred for both ${ }^{15} \mathrm{~N}$ and ${ }^{13} \mathrm{C}$ (Turner et al. 1983; Benner et al. 1984; Zieman et al. 1984, Focken and Becker 1998). However, until there is specific knowledge on decomposition processes and its consequences for stable isotope signatures in the detritus, most studies will have to assume no fractionation (Phillips and Gregg 2003). It is also important to point out that harpacticoid copepod samples in this study comprise several different species, which may vary 
substantially in their diet (e.g. Carman and Fry 2002). The isotope values for harpacticoids are therefore overall means, which are useful for ecosystem analysis but provides no evidence of the specific diet of different species. Ultimately, increasing the number of replicates of organisms would ensure better means and a greater variability in the stable isotopic signatures, which would add certainty to both the mixing model and graphical analyses.

\section{Detritus composition}

The mixing model consistently identified seston and MPB as major contributors to the bulk of estuarine detritus, though the detritus composition varied both within and between estuaries.

Obviously these results were clouded by the detritus contamination of MPB samples, but graphical analysis of the stable isotope signatures of non-MPB sources indicates that mixing model estimates were realistic. The apparent spatial variability could reflect the variability in $\delta^{13} \mathrm{C}$ and $\delta^{15} \mathrm{~N}$ values of primary producers within and between estuaries (Phillips and Gregg 2003) but also the spatial variability in the abundance of different primary producers. For example, in Leschenault Inlet where fringing saltmarsh is reduced due to development, the potential contributions of phytoplankton and MPB were generally higher in comparison with the Walpole-Nornalup Estuary. Furthermore, relatively large and consistent contributions of saltmarsh were found close to the mouth of Collie River (L2 and L1) in Leschenault Inlet, and near the Walpole River (W3) and Frankland River mouth (W2) in Walpole-Nornalup Estuary where saltmarsh was a conspicuous component of the fringing vegetation (pers. obs.). This association between detritus composition and proximity to rivers is consistent with earlier findings (e.g. Haines 1976; Zieman et al. 1984; Loneragan and Bunn 1997). However, whether detritus at these sites comprises mainly riverine or estuarine vegetation cannot be 
determined, as riparian plants in freshwater systems have similar $\delta^{13} \mathrm{C}$ to many saltmarsh species (Bunn and Boon 1993). Conversely, in both estuaries, other primary producers dominated the contributions to detritus at sites closer to the ocean and in regions with little fringing saltmarsh. Hence seagrass showed high contributions to detritus at sites where living seagrass was abundant (e.g. W2) and the introduced grass Paspalum vaginatum, which covered large areas adjacent to the estuaries, contributed substantially to detritus at some sites in both estuaries (i.e. W3, L2 and L3), indicating that human development had impacted directly on the detritus composition.

\section{Flow of detritus to invertebrates and fish}

Benthic copepods are known to feed partially on detritus (David et al. 1985; Higgins and Thiel 1988; Couch 1989; Carman and Fry 2002) and the relative contribution of different primary producers to the detritus in these estuaries should to somedegree be reflected in the harapacticoid food. At most sites, however, the composition of harpacticoid food differed slightly from that of detritus. This difference could reflect the known ability of benthic meiofauna to selectively assimilate essential elements from their food (Zieman et al. 1984; Couch 1989; Riera et al. 1996; Coull 1999), and, in this case, harpacticoids preferentially assimilating specific components from detritus or grazing on MPB (Montagna 1995, Carman and Fry 2002). For example, at W1 and W2 in Walpole-Nornalup Estuary, seagrasses were the most likely sources of $\mathrm{C}$ and $\mathrm{N}$ for harpacticoid copepods, while detritus at these sites consisted of a more even mix of primary producers. Furthermore, for some sites in Leschenault Inlet, harpacticoid copepods showed a slight preference for the saltmarsh component in detritus, indicating that the level of selective assimilation can vary both within 
and between estuaries. Other meiofauna had stable isotopic signatures suggesting microphytobenthic algae (MPB) as the main food, and at least for nematodes, this is consistent with earlier findings (Higgins and Thiel 1988; Riera et al. 1996, Carman and Fry 2002, Moens et al. 2002, 2005). MPB samples were, however, contaminated with detritus and depending on how the stable isotope values of MPB were affected by the contamination, detritus could account for up to $20 \%$ of its estimated contribution.

The expected enrichment of $0-1 \%$ ofor ${ }^{13} \mathrm{C}$ and $3-4 \%$ for ${ }^{15} \mathrm{~N}$ per trophic level (DeNiro and Epstein 1978, 1981) was often not observed between macroinvertebrate consumers and their potential food sources. For example, Nereids and Plathelminths in Walpole-Nornalup had very low $\delta^{15} \mathrm{~N}$ values for a scavenging behaviour. Furthermore, there was considerable overlap in stable isotopic signatures, especially in Walpole-Nornalup, indicating a lack of discrete trophic levels. Mainly though, this reflects the high abundance of omnivorous and generalist feeders among estuarine invertebrates (Shephard and Thomas 1982, 1989). Still there were some indications of trophic enrichment, especially in Leschenault Inlet, and certain invertebrates constituted the same trophic level in both estuaries. For example, bivalves, i.e. Tellina sp. and Katelysia $s p$., had ${ }^{13} \mathrm{C}$ and ${ }^{15} \mathrm{~N}$ contents relatively similar to detritus and phytoplankton, consistent with a filter-feeding behaviour. Medium-sized crustaceans appeared to feed on detritus, MPB and meiofauna, consistent with their presumed food preferences (Robertson 1988; Loneragan and Bunn 1997; Coull 1999). Larger crustaceans generally constituted a higher trophic level, reflecting a scavenging or predatingbehaviour. These invertebrates thus consumed MPB and the bulk of estuarine detritus either directly, or indirectly, through smaller prey. 
Fish collected during this study covered a large range of feeding groups, which explains the high degree of variability in $\delta^{13} \mathrm{C}$ and $\delta^{15} \mathrm{~N}$ values. This variability, particularly in $\delta^{15} \mathrm{~N}$, partly reflects the stepwise enrichment in ${ }^{15} \mathrm{~N}$ and ${ }^{13} \mathrm{C}$ from mainly detritivorous fish to carnivorous fish. Overall, the trophic positions of fish species in this study, based on their $\delta^{13} \mathrm{C}$ and $\delta^{15} \mathrm{~N}$ values, are consistent with those derived from earlier studies (e.g. Holt 1978; Humphries et al. 1992 ; Gill and Potter 1993; Humphries and Potter 1993; Last and Stevens 1994; Compagno and Niem 1997; Hyndes et al. 1997; Potter and Hyndes 1999; de Lestang et al. 2000; Sarre et al.2000). Larger fish had clearly fed on invertebrates and other fish, which in turn had fed on grazing and detritivorous invertebrates or directly on detritus. This suggested that all the major primary producers, including seagrass, were providing fish with nutrients in these estuaries.

This study adds further insight into the importance of seston and microphytobenthos in estuarine food webs, providing quantitative estimates of the relative contributions of these primary producers to the bulk of estuarine detritus and detritus to first order consumers. In addition, the study showed that the relative contribution of saltmarsh might vary within and between estuaries, foremost in relation to the proximity of sites to rivers and the density of fringing saltmarsh. Hence, fish consumption of estuarine meio - and macrofauna does not necessarily imply that saltmarsh is contributing to fish production. Connolly (2003) has shown that many estuarine species are capable of making significant shifts in their diets following changes to habitats. In the absence of historical (pre-disturbance) data, it is not possible to draw conclusions on any shifts in foodweb structure or secondary production that may have resulted from shifts in the primary producer base of these two estuaries. However, although results from this study imply that the loss of fringing saltmarsh from estuaries could have implications for the entire estuarine food web, generally, the significance of such a 


\section{ACCEPTED MANUSCRIPT}

losses will be site- and estuary-specific, and a function of the magnitude of loss, the availability of alternative primary producers that contribute to detrital and grazing food-chains and the feeding plasticity of the resident fauna. 


\section{References}

Barrie A, Prosser SJ (1996) Mass Spectrometry of Soils: Automated Analysis of LightElement Stable Isotopes by Isotope Ratio Mass Spectrometry, Marcel Dekker Inc., New York

Benner R, Maccubin AE, Hodson RE (1984) Preparation, characterization and microbial degradation of specifically radiolabelled $\left({ }^{14} \mathrm{C}\right)$ lignocelluloses from marine and freshwater macrophytes. Applied and Environmental Microbiology 47: 381 -389

Bulman C, Althaus F, He X, Bax NJ, Williams A (2001) Diets and trophic guilds of demersal fish of the south-eastern Australian shelf. Marine and Freshwater Research52(4): 537-548

Bunn SE, Boon PI (1993) What sources of organic carbon drive food webs in billabongs? A study based on stable isotope analysis. Oecologia 96: 85-94

Cabana G, Rasmussen JB (1996) Comparison of aquatic food chains using nitrogen isotopes. Proceedings in the National Academy of Science, USA 93: 10844-10847

Cammen LM (1980) The significance of microbial carbon in the nutrition of the deposit feeding polychaete, Nereis succinea. Marine Biology 61: 9-20

Carman KR, Fry B (2002) Small-sample methods for $\delta^{12} \mathrm{C}$ and $\delta^{15} \mathrm{~N}$ analysis of the diets of marsh meiofaunal species using natural abundance and tracer-addition isotope techniques. Marine Ecology Progress Series 240: 85-92

Carman KR, Thistle D (1985) Microbial food partitioning by three species of benthic copepods. Marine Biology 88: $143-148$

Castellanos DL, Rozas LP (2001) Nekton use of submerged aquatic vegetation, marsch, and shallow unvegetated bottom in the Atchafalaya river delta, a Louisiana tidal freshwater ecosytem. Estuaries 24: 184-197

Charteris A, Deeley D (2000) Hydrodynamics of Leschenault Inlet, Western Australia. Journal of the Royal Society of Western Australia 83: 251-254 
Compagno LJV, Niem VH (1997) In: K.E. Carpenter and V.H. Niem (eds.) FAO identification guide for fishery purposes: The Living Marine Resources of the Western Central Pacific, FAO, Rome.

Connolly RM (2003) Differences in trophodynamics of commercially important fish between artificial waterways and natural coastal wetlands. Estuarine and Coastal Shelf Science 58: 929-936

Constable AJ (1999) Ecology of benthic macro -invertebrates in soft-sediment environments: A review of progress towards quantitative models and predictions. Australian Journal of Ecology 24: 452-476

Cook PLM, Revill AT, Clementson LA, Volkman JK (2004) Carbon and nitrogen cycling on intertidal mudflats of a temperate Australian estuary. III. Sources of organic matter. Marine Ecology Progress Series 280: 55-72

Couch CA (1988) A procedure for extracting large numbers of debris free living nematodes from muddy marine sediments, Transactions of the American Microscopic Society 107: 96100

Couch CA (1989) Carbon and Nitrogen stable isotopes of meiobenthos and their food resources. Estuarine and Coastal Shelf Scien ce 28: $433-441$

Coull BC (1999) Role of meiofauna in estuarine soft-bottom habitats. Australian Journal of Ecology 24: 327-343

Coull BC, Greenwood JG, Fielder DR, Coull BA (1995) Subtropical Australian juvenile fish eat meiofauna: experiments with winter whiting Sillago maculata and observations on other species. Marine Ecology Progress Series 125: 13-19

David M, Checley JR, Entzeroth LC (1985) Elemental and isotopic fractionation of carbon and nitrogen by marine, planktonic copepods and implications to the marine nitrogen cycle. Journal of Plankton Research 7(4): 553 -568 
de Lestang S, Platell ME, Potter IC (2000) Dietary composition of the blue swimmer crab Portunus pelagicus (L): Does it vary with body size and shell state and between estuaries? Journal of Experimental Marine Biology and Ecology 246: 241-257

DeNiro MJ, Epstein S (1978) Influence of the diet on the distribution of carbon isotopes in animals. Geochimica et Cosmochimica Acta 42: $495-506$

DeNiro MJ, Epstein S (1981) Influence of the diet on the distribution of nitrogen isotopes in animals. Geochimica et Cosmochimica Acta 45: 341 -353

Focken U, Becker K (1998) Metabolic fractionation of stable carbon isotopes: implications of different proximate compositions for studies of the aquatic food webs using stable isotope for carbon data. Oecologia 115: 337-343.

Gill HS, Potter IC (1988) Spatial segregation amongst goby species within an Australian estuary, with a comparison of the diets and salinity tolerance of the two most abundant species. Marin e Biology 117: 515-526

Guy RD, Read DM, Krouse HR (1980) Shifts in carbon isotopes ratios of two $\mathrm{C}_{3}$ halophytes under natural and artificial conditions. Oecologia 44: 240-247

Haines E B (1976) Stable carbon isotope ratios in the biota soils and tidal water of a Georgia salt marsh. Estuarine Coastal and Marine Science 4: 609-616

Harty C, Cheng D (2003) Ecological assessment and strategies for the management of mangroves in Brisbane water - Gosford, New South Wales, Australia. Landscape and Urban Planning 62:219-240

Higgins RP, Thiel H (1988) Introduction to the Study of Meiofauna, Smithsonian Institution Press, Washington D.C.

Hillman K, McComb AJ, Bastyan G, Paling E (2000) Macrophyte abundance and distribution in Leschenault Inlet, an estuarine system in south -western Australia. Journal of the Royal Society of Western Australia 83: 349-355 
Hodgkin EP (1998) The future of the estuaries of south -western Australia. Journal of the Royal Society of WA 81(4): 225-228

Hodgkin EP, Clark R (1988). Estuaries and Coastal Lagoons of South Western Australia, Nornalup and Walpole Inlets, Perth, Environmental Protection Authority, Perth, WA: 18

Hyndes GA, Platell ME, Potter IC (1997) Relationships between diet and body size, mouth morphology, habitat and movements of six sillginid species in coastal waters: implications for resource partioning. Marine Biology 128: 585-598

Humphries P, Hyndes GA, Potter IC (1992). Comparison between the diets of distant taxa (teleost and cormorant) in an Australian estuary. Estuaries 15:3: 327-334

Humphries P, Potter IC (1993) Relationship between the habitat and diet of three species of atherinids and three species of gobies in a temperate Australian estuary. Marine Biology 116: 193-204

Kennish MJ (1990) Ecology of Estuaries, Vol 2., Biological Aspects, CRC Press, Boca Raton, Florida.

Knogge T, Schirmer M, Schuchardt B (2004) Landscape scale socio-economics of sea-level rise. IBIS 146: 11-17

Kwak TJ, Zedler JB (1997) Food web analysis of southern California coastal wetlands using multiple stable isotopes. Oecologia 110: 262 -277

Last PR, Stevens JD (1994) In: Sharks and rays of Australia. CSIRO, Australia, pp 447, 453 454.

Le Point G, Nyssen F, Gobert S (2000) Relative importance of a seagrass bed and its adjacent epilithic algal community in consumer diets. Marine Biology 136: 513-518

Loneragan NR, Bunn SE (1997) Are mangroves and seagrasses sources of organic carbon for panaeid prawns in a tropical Australian estuary? A multiple stable isotope study. Marine 
Biology 130: 289-300

Mazumder D, Saintilan N, Williams RJ (2006) Trophic relationships between itinerant fish and crab larvae in a temperate Australian saltmarsh. Marine Freshwater Research 57 (2): 193 199

McCutchan JH, Lewis MW, Kendall C and McGrath CC (2003) Variation in trophic shift for stable isotope ratios of carbon, nitrogen and sulfur. Oikos 102: $378-390$

Moens T, Bouillon S, Gallucci F (2005) Dual stable isotope abundances unravel trophic position of estuarine nematodes. Journal of the Marine Biological Association of the UK 85: $1401-1407$.

Moens T, Luyten C, Middleburg JJ, Herman PMJ, Vincx M (2002) Tracing organic matter sources of estuarine tidal flat nematodes with stable carbon isotopes. Marine Ecology Progress Series 234: $127-137$

Montagna PA (1995) Rates of metazoan meiofaunal herbivory: a review. Vie Mielieu 45: 1 10

Montagna PA, Yoon BA (1991) The effect of freshwater inflow on meiofaunal consumption of sediment bacteria and microphytobenthos in San Antonio Bay, Texas. Estuarine and Coastal Shelf Science 33:529-547

Odum HT (1980) The status of three ecosystem level hypotheses regarding salt marsh estuaries: tidal subsidy, outwelling and detritus based food chains. Estuarine Perspectives. V. S. Kennedy, Academic press, New York, p $485-495$.

Pen L, Semeniuk V, Semeniuk CA (2000) Peripheral wetland habitats and vegetation of the Leschenault Inlet estuary. J Roy Soc West Aust 83: 293-396

Phillips DL (2001) Mixing models in analyses of diet using multiple stable isotopes: A critique. Oecologia 127: 166-170

Phillips DL, Gregg JW (2003) Source partitioning using stable isotopes: coping with too 
many sources. Oecologia 136: $261-269$

Potter IC, Hyndes GA (1999). Characteristics of the ichtyofaunas of southwestern Australian estuaries, including comparisons with holarctic estuaries elsewhere in temperate Australia: A review. Australian Journal of Ecology 24: 395-421

Riera P, Hubas C (2003) Trophic ecology of nematodes from various microhabitats of the Roscoff Aber Bay (France): importance of stranded macroalagae evid enced through $\delta^{12} \mathrm{C}$ and $\delta^{15} \mathrm{~N}$. Marine Ecology Progress Series 260: $151-159$

Riera P, Richard P, Gremare A, Blanchard G (1996) Food source of intertidal nematodes in the Bay of Marennes-Oleron (France), as determined by dual stable isotope analysis. Marine Ecology Progress Series 142: 303-309

Robertson AI (1988) Abundance, diet and predators of juvenile banana prawns, Panaeus merguiensis, in a tropical mangrove estuary. Australian Journal of Marine and Freshwater Research 39: $467-478$

Rolff C (2000) Seasonal variation in $\delta^{13} \mathrm{C}$ and $\delta^{15} \mathrm{~N}$ of size-fractionated plankton at a coastal station in the northern Baltic proper. Marine Ecology Progress Series 203: $47-65$

Sarre GA, Platell ME, Potter IC (2000) Acanthopagrus butcheri in four estuaries and a coastal lake vary with body size and season and within and amongst these water bodies. Journal of Fish Biology 56: 103-122

Shepherd SA, Thomas IM (1982) Marine invertebrates of southern Australia, part 1. D. J. Woolman Government Printer, South Australia.

Shepherd SA, Thomas IM (1989) Marine invertebrates of southern Australia, part 2. South Australian Government Printing Division, Adelaide.

Smith BN, McMillan C (1976) Influence of carbon source oxygen concentration, light intensity and temperature of $C^{13} / C^{12}$ ratios in plant tissues. Botanical Gazette 137: 99-104 
Staddon PL (2004) Carbon isotopes in functional soil ecology. Trends in Ecology and Evolution 19(3): 148-154

Thresher RE (1992) Seagrass detritus as the basis of a coastal planktonic food chain. Limnology and Oceanography 37: 1754-1758

Troughton JH, Card KA (1975) Temperature effects on the carbon isotope ratio of $\mathrm{C}_{3}, \mathrm{C}_{4}$ and crussulacean acid metabolism plants. Planta 123: 185-190

Turner GL, Bergersen FJ, Tantala H (1983) Natural enrichment of ${ }^{15} \mathrm{~N}$ during decomposition of plant material in soil. Soil Biology and Biochemistry 15(4): 495-497

Vanderklift MA, Ponsard S (2003) Sources of variation in consumer-diet $\delta^{15} \mathrm{~N}$ enrichment: a meta-analysis. Oecologia 136: 169-182

Wada E, Mizutani H (1991) The Use of Stable Isotopes for Food Web Analysis. Critical Review in Food Science and Nutrition 30: 361-371

Zieman JC, Macko SA, Mills AL (1984) Role of seagrass and mangroves in estuarine food webs: temporal and spatial changes in stable isotopic composition and amino acid content during decomposition. Bulletin of Marine Science 35(3): 380-392 


\section{Figure legends}

Fig. 1. Locations and maps of the two sampled estuaries Leschenault Inlet on the west coast and Walpole-Nornalup Estuary on the south coast of West Australia and the positions of sites in each estuary.

Fig. 2. Mixing model outputs showing the range of the potential contribution of different primary producers to detritus at all sites in Walpole-Nornalup Estuary and Leschenault Inlet. Shaded boxes span the $75^{\text {th }}$ (top) to $25^{\text {th }}$ (bottom) percentiles with the central lines indicating the $50^{\text {th }}$ percentile. The vertical lines outside the boxes indicate the $90^{\text {th }}$ (top) and $10^{\text {th }}$ (bottom) percentiles and the outliers are indicated by dots. MPB $=$ Microphytobenthos.

Fig. 3. Mixing model outputs showing the range of the potential contribution of different primary producers to harpacticoid copepods at all sites in Walpole-Nornalup Estuary and Leschenault Inlet. Shaded boxes span the $75^{\text {th }}$ (top) to $25^{\text {th }}$ (bottom) percentiles with the central lines indicating the $50^{\text {th }}$ percentile. The vertical lines outside the boxes indicate the $90^{\text {th }}$ (top) and $10^{\text {th }}$ (bottom) percentiles and the outliers are indicated by dots. MPB = Microphytobenthos.

Fig. 4. The range of $\delta^{13} \mathrm{C}$ and $\delta^{15} \mathrm{~N}$ values for different groups of primary producers, $\delta^{13} \mathrm{C}$ and $\delta^{15} \mathrm{~N}$ values for detritus at each site, and mean $\delta^{13} \mathrm{C}$ and $\delta^{15} \mathrm{~N}$ values for invertebrates and fish across sites in Walpole-Nornalup Estuary: $\therefore=$ primary producers, $\mathrm{t}=$ detritus, $\bullet=$ meiofauna, $₫=$ macrofauna, ? = fish. See Table 2 for full names of species.

Fig. 5. The range of $\delta^{13} \mathrm{C}$ and $\delta^{15} \mathrm{~N}$ values for different groups of primary producers, $\delta^{13} \mathrm{C}$ and $\delta^{15} \mathrm{~N}$ values for detritus at each site, and mean $\delta^{13} \mathrm{C}$ and $\delta^{15} \mathrm{~N}$ values for invertebrates and fish 


\section{ACCEPTED MANUSCRIPT}

across sites in Leschenault Inlet: $\therefore=$ primary producers, $\uparrow=$ detritus, $\bullet=$ meiofauna, $\uparrow=$ macrofauna, $?=$ fish. See Table 2 for full names of species. 


\section{Tables}

Table 1. Mean $\delta^{13} \mathrm{C}$ and $\delta^{15} \mathrm{~N}$ values and standard deviation (sd) for detritus, primary

producers and meiofauna at each site in the Walpole-Nornalup estuary and Leschenault Inlet.

4 replicates $(\mathbf{n}=4)$ were used for most flora and fauna. $\mathbf{x}$ indicates a pooled estimate.

\begin{tabular}{|c|c|c|c|c|c|c|c|c|}
\hline \multirow{2}{*}{$\begin{array}{l}\text { Location } \\
\text { WalpoleNornalup }\end{array}$} & \multirow[t]{2}{*}{ Functional group } & \multirow[t]{2}{*}{ Name/Group } & \multirow{2}{*}{$\begin{array}{l}\delta^{13} \mathrm{C} \\
\mathrm{W} 1\end{array}$} & \multicolumn{4}{|c|}{$\delta^{15} \mathbf{N}$} & \multirow[b]{2}{*}{ W 3} \\
\hline & & & & W 2 & W 3 & W 1 & W 2 & \\
\hline & Detritus & & $-19.6(0.1)$ & $-19.7(0.1)$ & $-21.7(0.4)$ & $4.6(0.1)$ & $6.0(0.3)$ & $5.2(0.4)$ \\
\hline & Terrestrial vegetation & Juncus kraussi & $-24.1(0.6)$ & $-25.7(0.9)$ & $-25.7(0.2)$ & $6.3(0.5)$ & $8.6(0.4)$ & $4.6(0.1)$ \\
\hline & & Paspalum vaginatum & & & $-13.1(0.8)$ & & & $5.5(0.2)$ \\
\hline & & Halosarcia sp. & & & $-28.6(0.3)$ & & & $3.5(0.6)$ \\
\hline & Seagrasses & Halophila ovalis & $-10.4(0.6)$ & $-15.8(1.2)$ & & $5.0(0.2)$ & $4.5(0.4)$ & \\
\hline & & Zostera tasmanica & $-9.9(0.1)$ & & & $5.0(0.7)$ & & \\
\hline & Aquatic vegetation & Seston & $-20.2(\mathrm{x})$ & $-21.6(\mathrm{x})$ & $-22.0(\mathrm{x})$ & $3.9(\mathrm{x})$ & $7.5(\mathrm{x})$ & $6.0(\mathrm{x})$ \\
\hline & & Microphytobenthos & $-15.7(\mathrm{x})$ & $-16.6(\mathrm{x})$ & $-20.8(\mathrm{x})$ & $4.7(\mathrm{x})$ & $7.5(\mathrm{x})$ & $7.5(\mathrm{x})$ \\
\hline & & Chaetomorpha linum & $-20.1(1.3)$ & $-21.8(1.0)$ & & $4.1(0.1)$ & $5.4(0.2)$ & \\
\hline & & Gracilaria gracilis & $-34.4(0.2)$ & $\theta$ & & $4.9(0.4)$ & & \\
\hline & Zooplankton & Zooplankton & $-17.6(\mathrm{x})$ & $-22.3(\mathrm{x})$ & $-22.1(x)$ & $4.2(\mathrm{x})$ & $7.5(\mathrm{x})$ & $5.1(\mathrm{x})$ \\
\hline & Meiofauna & Nematodes & $-17.3(\mathrm{x})$ & $-14.2(\mathrm{x})$ & & $5.3(\mathrm{x})$ & $5.2(\mathrm{x})$ & \\
\hline & & Harpacticoid copepod & s- $-11.3(x)$ & $-17.4(x)$ & $-20.2(x)$ & $4.4(\mathrm{x})$ & $6.5(\mathrm{x})$ & $8.8(\mathrm{x})$ \\
\hline & & Calanoid copepods & $-12.1(\mathrm{x})$ & $-16.1(x)$ & $-20.7(\mathrm{x})$ & $7.9(\mathrm{x})$ & $6.1(\mathrm{x})$ & $8.6(\mathrm{x})$ \\
\hline & & Insect larvae & & $-16.8(x)$ & & & $6.5(\mathrm{x})$ & \\
\hline eschenault Inlet & & & L 1 & L 2 & L 3 & L 1 & L 2 & L 3 \\
\hline & Det & & $-16.9(0.5)$ & $-14.5(0.0)$ & $-16.7(0.2)$ & $3.7(0.1)$ & $6.1(0.1)$ & $6.9(0.3)$ \\
\hline & Terrestrial vegetation & Juncus kraussi & $-25.1(0.3)$ & & $-25.3(0.2)$ & $2.7(0.4)$ & & $11.3(1.0)$ \\
\hline & & Halosarcia sp. & $-27.3(0.6)$ & $-27.6(0.2)$ & $-27.4(0.1)$ & $4.3(0.8)$ & $6.7(0.3)$ & $10.4(0.8)$ \\
\hline & & Paspalum vaginatum & & $-13.5(0.2)$ & $-12.3(0.8)$ & & $6.6(0.5)$ & $9.3(0.3)$ \\
\hline & & Halophila ovalis & $-8.2(0.1)$ & $-8.1(0.2)$ & $-8.4(0.1)$ & $2.8(0.1)$ & $3.2(0.7)$ & $5.0(0.5)$ \\
\hline & & Zostera tasmanica & $-8.7(0.4)$ & & & $3.0(0.4)$ & & \\
\hline & & Seston & $-16.6(\mathrm{x})$ & $-16.5(x)$ & $-17.1(\mathrm{x})$ & $4.4(\mathrm{x})$ & $5.0(\mathrm{x})$ & $8.8(\mathrm{x})$ \\
\hline & & Microphytobenthos & $-15.4(\mathrm{x})$ & $-15.7(x)$ & $-17.6(x)$ & $4.3(\mathrm{x})$ & $5.7(\mathrm{x})$ & $5.9(\mathrm{x})$ \\
\hline & & Chaetomorpha linum & & $-22.2(0.2)$ & & & $5.7(0.7)$ & \\
\hline & & Polysifonia sp. & & & $-19.3(0.2)$ & & & $7.0(0.2)$ \\
\hline & & Hormophysa triquetro & $a-12.9(0.1)$ & & & $2.5(1.1)$ & & \\
\hline & Zooplankton & Zooplankton & $-12.5(\mathrm{x})$ & $-15.7(\mathrm{x})$ & $-17.7(x)$ & $2.4(\mathrm{x})$ & $5.4(\mathrm{x})$ & $10.2(\mathrm{x})$ \\
\hline & Meiofauna & Larvae $(P$. pelagicus $)$ & $-16.1(\mathrm{x})$ & $-15.8(\mathrm{x})$ & $-17.3(x)$ & $3.5(\mathrm{x})$ & $7.1(\mathrm{x})$ & $7.4(\mathrm{x})$ \\
\hline & & Harpacticoid copepod & s $-15.5(x)$ & $-15.0(x)$ & $-17.6(x)$ & $4.5(\mathrm{x})$ & $6.6(\mathrm{x})$ & $7.8(\mathrm{x})$ \\
\hline & & Calanoid copepods & $-14.4(\mathrm{x})$ & $-15.4(\mathrm{x})$ & & $4.9(\mathrm{x})$ & $7.0(\mathrm{x})$ & \\
\hline
\end{tabular}


Table 2. Mean $\delta^{13} \mathrm{C}$ and $\delta^{15} \mathrm{~N}$ values and standard deviation (sd) among sites for macrofauna and fish, sampled in the Walpole-Nornalup estuary and Leschenault Inlet. 9 replicates (three from each site $)(\mathbf{n}=9)$ were used for most fauna. $\mathbf{x}$ indicates a single or pooled estimate.

\begin{tabular}{|c|c|c|c|c|}
\hline \multicolumn{3}{|c|}{ Location Functional group Name/Group } & $\delta^{13} \mathbf{C}$ & $\delta^{15} \mathbf{N}$ \\
\hline \multirow{23}{*}{$\begin{array}{l}\text { Walpole- } \\
\text { Nornalup }\end{array}$} & \multirow[t]{2}{*}{ Worms } & Nereids & $-14.0(6.67)$ & $4.2(1.8)$ \\
\hline & & Platyhelminthes & $-12.2(5.3)$ & $4.4(0.3)$ \\
\hline & \multirow[t]{6}{*}{ Crustaceans } & Amphipods & $-13.9(5.0)$ & $7.4(1.8)$ \\
\hline & & Tanaidae sp. & $-14.1(3.8)$ & $7.95(1.5)$ \\
\hline & & Palaemonsp. & $-12.7(\mathrm{x})$ & $6.6(\mathrm{x})$ \\
\hline & & Ovalipes australiensis & $-17.9(\mathrm{x})$ & $10.1(\mathrm{x})$ \\
\hline & & Panaeus latisculatus & $-15.3(0.0)$ & $7.1(0.1)$ \\
\hline & & Portunus pelagicus & $-17.1(0.7)$ & $8.2(0.4)$ \\
\hline & \multirow[t]{2}{*}{ Gastropods } & Nassarius sp. & $-18.4(2.7)$ & $5.0(1.7)$ \\
\hline & & Philine angasi & $-13.0(0.4)$ & $7.45(0.1)$ \\
\hline & \multirow[t]{2}{*}{ Bivalves } & Katelysia sp. & $-20.1(0.9)$ & $5.1(0.3)$ \\
\hline & & Tellina sp. & $-20.9(0.1)$ & $4.9(2.5)$ \\
\hline & \multirow[t]{11}{*}{ Fish } & Favonigobius lateralis & $-14.4(3.1)$ & $7.3(0.7)$ \\
\hline & & Leptatherina presbyteroides - & $17.6(0.2)$ & $7.9(0.4)$ \\
\hline & & Acanthopagrus butcheri & $-18.3(0.2)$ & $10.2(0.6)$ \\
\hline & & Arripis georgianus & $-17.5(0.4)$ & $13.0(0.6)$ \\
\hline & & Arenigobius bifrenatus & $-17.4(0.1)$ & $10.0(0.0)$ \\
\hline & & Cnidoglanus macrocephalus & $-17.3(0.0)$ & $9.7(0.1)$ \\
\hline & & Platycephalus sp. & $-16.3(0.3)$ & $11.5(0.7)$ \\
\hline & & Pseudocaranx dentex & $-15.1(0.7)$ & $11.0(0.4)$ \\
\hline & & Mustelus antarcticus & $-14.3(1.1)$ & $13.0(0.7)$ \\
\hline & & Aptychotrema vincentiana & $-14.0(0.5)$ & $10.5(0.1)$ \\
\hline & & Myliobatis australis & $-13.1(0.1)$ & $11.1(0.1)$ \\
\hline Leschenault & \multirow[t]{3}{*}{ Worms } & Nereids & $-14.7(2.8)$ & $6.7(1.1)$ \\
\hline \multirow{25}{*}{ Inlet } & & Terebellidae sp. & $-13.1(x)$ & $10.4(\mathrm{x})$ \\
\hline & & Platyhelminthes & $-14.6(x)$ & $7.0(\mathrm{x})$ \\
\hline & \multirow[t]{23}{*}{ Crustaceans } & Amphipods & $-16.9(1.2)$ & $5.9(0.8)$ \\
\hline & & Tanaidae sp. & $-19.8(\mathrm{x})$ & $7.1(\mathrm{x})$ \\
\hline & & Palaemon sp. & $-13.4(0.6)$ & $8.95(0.5)$ \\
\hline & & Macrobrachium intermedium & $-12.4(\mathrm{x})$ & $8.0(\mathrm{x})$ \\
\hline & & inus pelagicus & $-10.8(0.5)$ & $9.8(0.4)$ \\
\hline & & Nassarius sp. & $-12.4(2.0)$ & $7.3(1.4)$ \\
\hline & & Favonigobius lateralis & $-11.0(0.9)$ & $9.1(1.8)$ \\
\hline & & Leptatherina presbyteroides & $-12.4(1.0)$ & $10.7(2.7)$ \\
\hline & & Torquigener pleurogramma & $-13.4(0.8)$ & $12.6(0.1)$ \\
\hline & & Engrualis australis & $-15.7(0.0)$ & $10.4(0.3)$ \\
\hline & & Pseudocaranx dentex & $-15.0(0.1)$ & $12.2(0.0)$ \\
\hline & & Hyporhamphus melanchir & $-14.3(0.0)$ & $9.4(0.5)$ \\
\hline & & Pomatomus saltatrix & $-14.0(0.1)$ & $13.0(0.7)$ \\
\hline & & Aldrichetta forsteri & $-13.9(0.1)$ & $11.6(0.3)$ \\
\hline & & Mugil cephalus & $-13.8(0.1)$ & $6.1(1.0)$ \\
\hline & & Contusus brevicaudus & $-13.7(0.0)$ & $12.0(0.4)$ \\
\hline & & Rhombosolea tapirina & $-13.3(0.5)$ & $11.1(0.4)$ \\
\hline & & Pagrus auratus & $-13.2(\mathrm{x})$ & $11.5(\mathrm{x})$ \\
\hline & & Apogon rueppellii & $-12.9(0.1)$ & $11.4(0.1)$ \\
\hline & & Arripis georgianus & $-12.7(0.1)$ & $12.7(0.1)$ \\
\hline & & Acanthopagrus butcheri & $-11.9(0.1)$ & $12.3(0.5)$ \\
\hline & & Sillaginodes punctata (large) & $-10.6(0.0)$ & $12.4(0.1)$ \\
\hline & & Myliobatis australis & $-10.5(2.1)$ & $10.5(1.3)$ \\
\hline
\end{tabular}




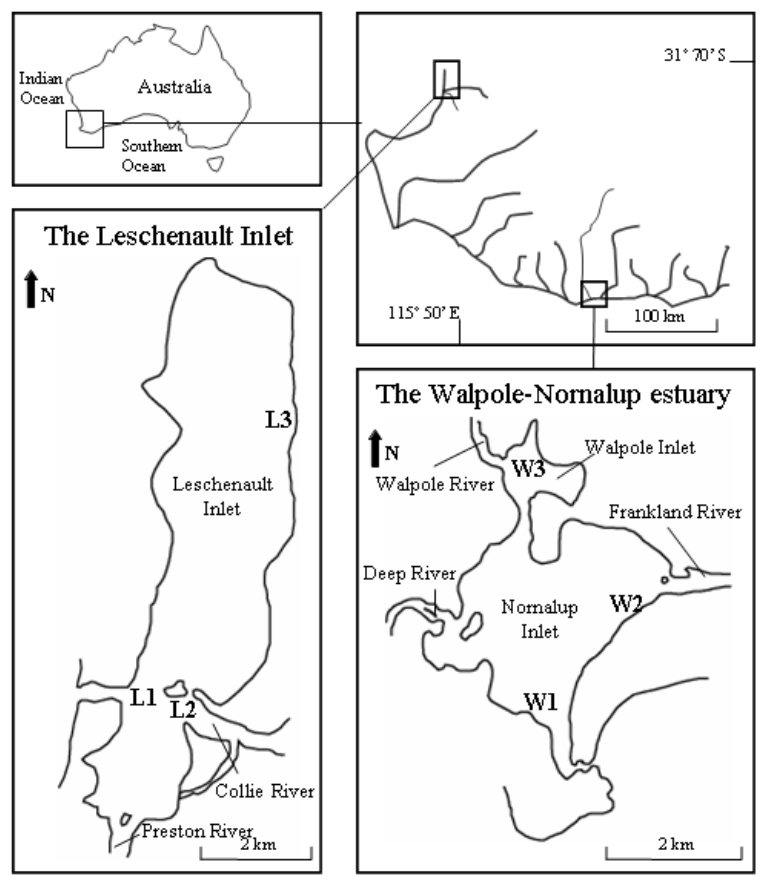

Svensson et al. Fig. 1 


\section{ACCEPTED MANUSCRIPT}

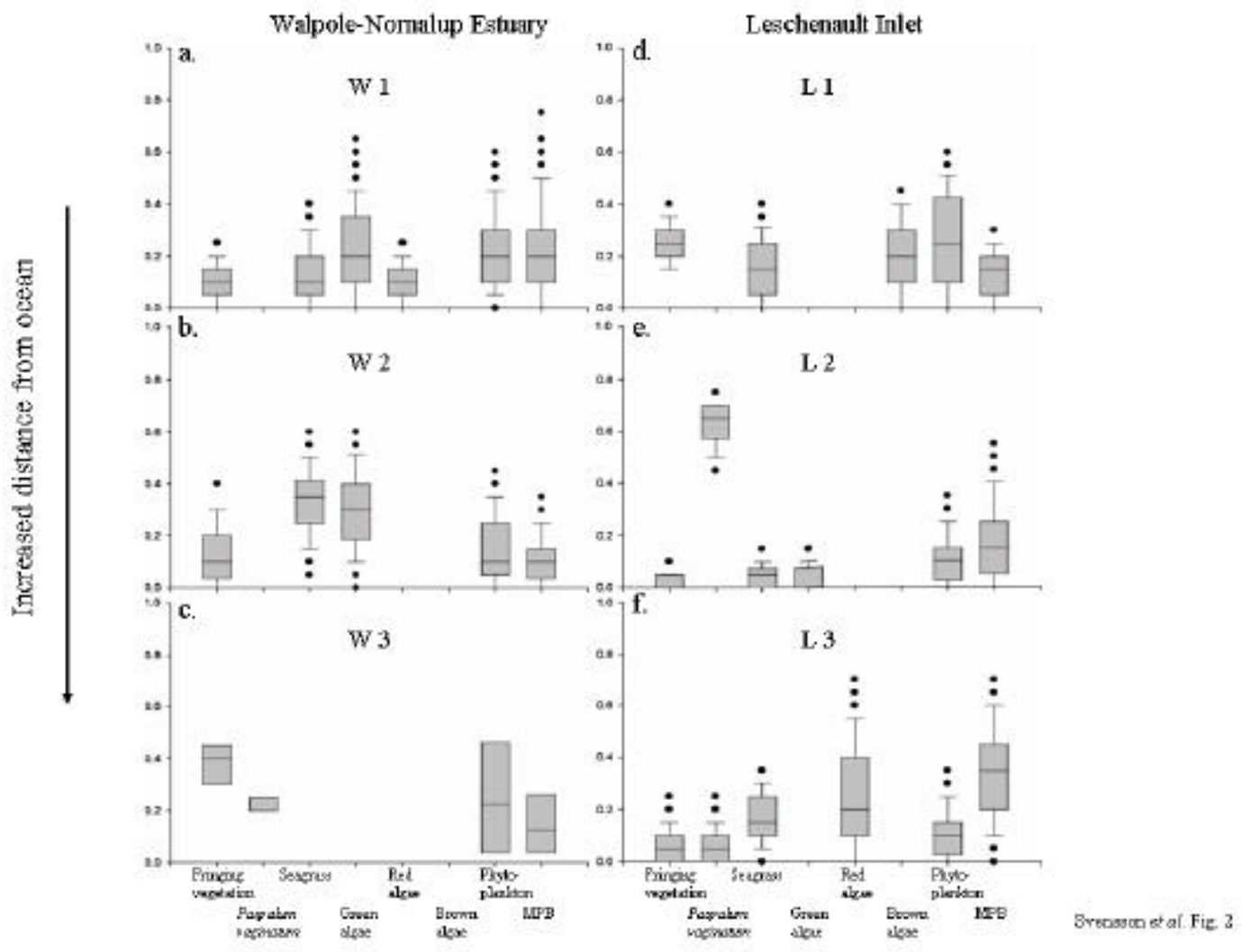




\section{ACCEPTED MANUSCRIPT}
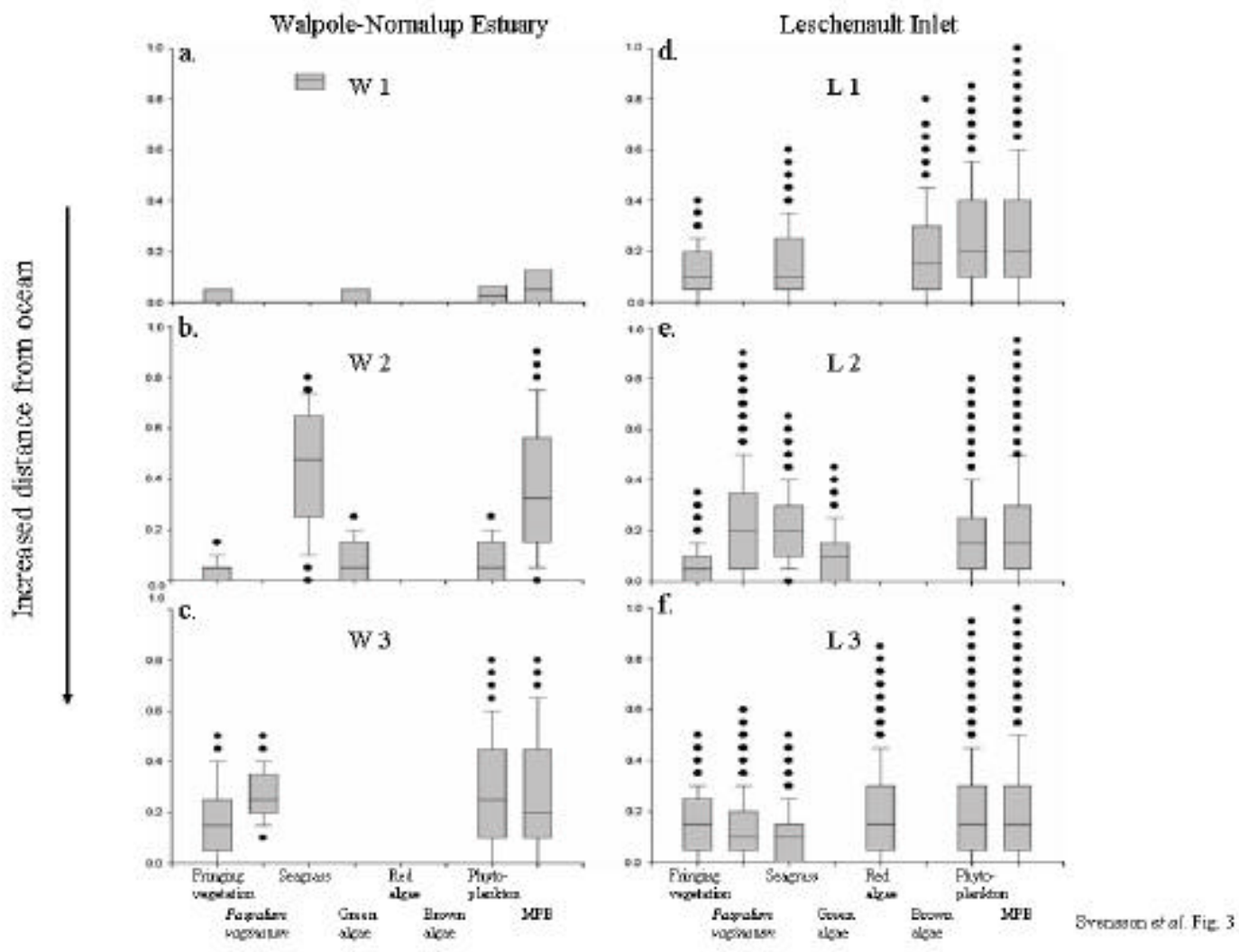


\section{ACCEPTED MANUSCRIPT}

Walpole-Nornalup Estuary

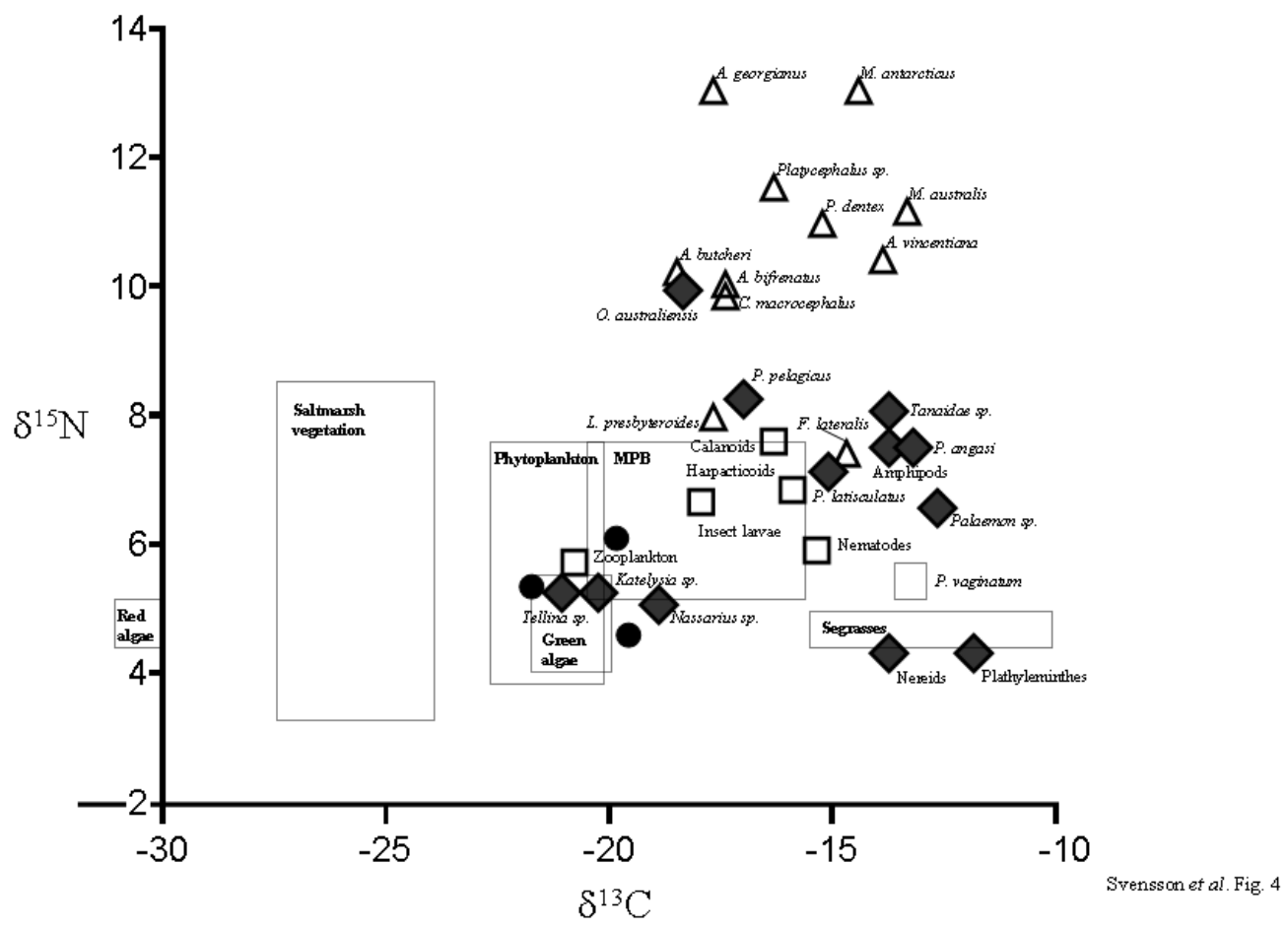




\section{ACCEPTED MANUSCRIPT}

Leschenault Inlet

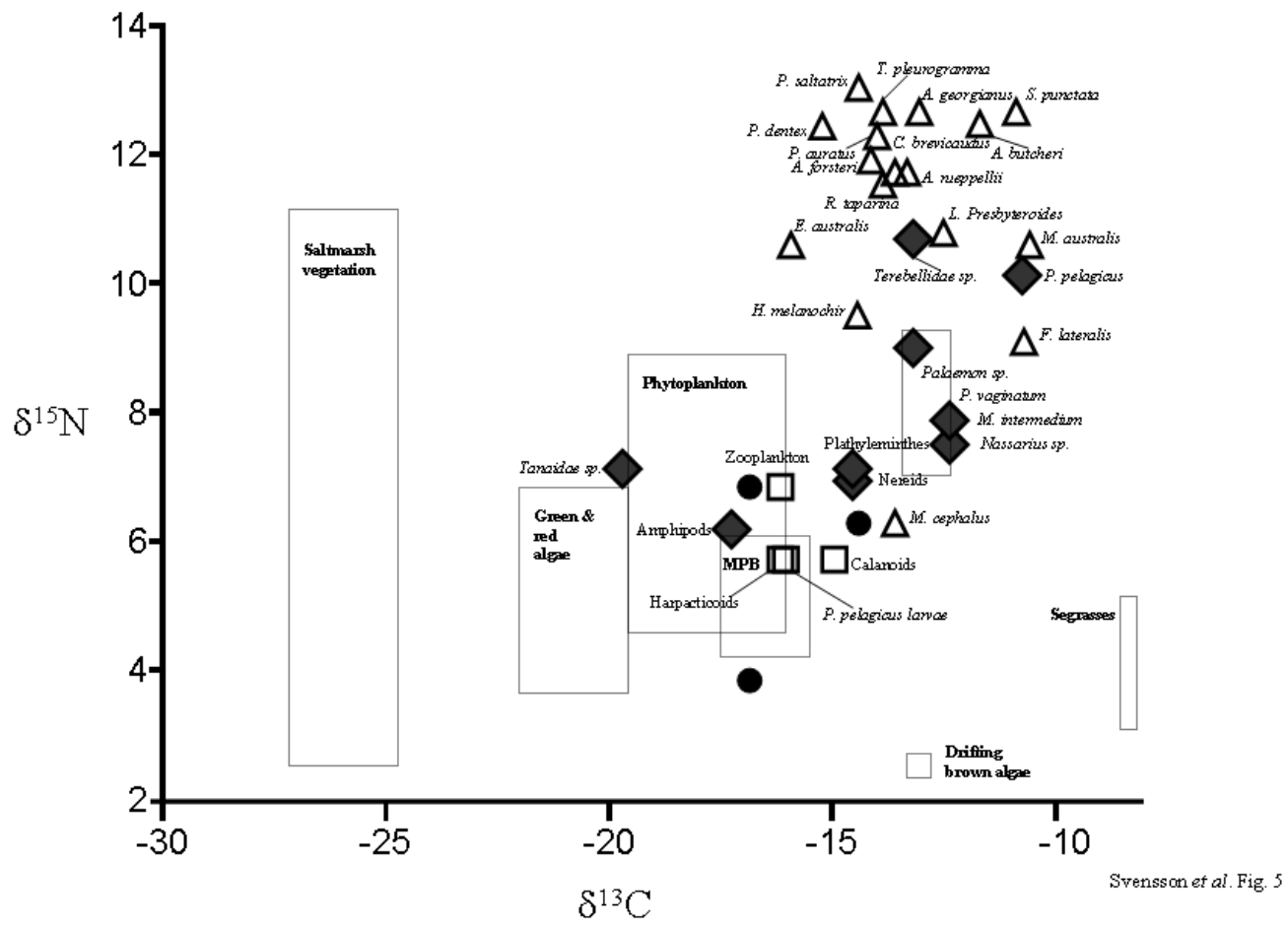

